\title{
HOTTIP and HOXA13 are oncogenes associated with gastric cancer progression
}

\author{
SHUAI CHANG ${ }^{1}$, JUNSONG LIU ${ }^{2}$, SHAOCHUN GUO ${ }^{1}$, SHICAI HE ${ }^{1}$, GUANGLIN QIU ${ }^{1}$, \\ JING LU $^{1}$, JIN WANG ${ }^{1}$, LIN FAN $^{1}$, WEI ZHAO ${ }^{1}$ and XIANGMING CHE ${ }^{1}$ \\ Departments of ${ }^{1}$ General Surgery and ${ }^{2}$ Otorhinolaryngology-Head and Neck Surgery, \\ The First Affiliated Hospital of Xi'an Jiaotong University, Xi'an, Shaanxi 710061, P.R. China
}

Received December 2, 2015; Accepted February 2, 2016

DOI: $10.3892 / o r .2016 .4743$

\begin{abstract}
A long non-coding RNA named HOTTIP (HOXA transcript at the distal tip) coordinates the activation of various 5' HOXA genes which encode master regulators of development through targeting the WDR5/MLL complex. HOTTIP acts as an oncogene in several types of cancers, whereas its biological function in gastric cancer has never been studied. In the present study, we investigated the role of HOTTIP in gastric cancer. We found that HOTTIP was upregulated in gastric cancer cell lines. Knockdown of HOTTIP in gastric cancer cells inhibited cell proliferation, migration and invasion. Moreover, downregulation of HOTTIP led to decreased expression of homeobox protein Hox-A13 (HOXA13) in gastric cancer cell lines. HOXA13 was involved in HOTTIP-induced malignant phenotypes of gastric cancer cells. Our data showed that the levels of HOTTIP and HOXA13 were both markedly upregulated in gastric cancer tissues compared with their counterparts in non-tumorous tissues. Furthermore, the expression levels of HOTTIP and HOXA13 were both higher in gastric cancer which was poorly differentiated, at advanced TNM stages and exhibited lymph node-metastasis. Spearman analyses indicated that HOTTIP and HOXA13 had a highly positive correlation both in non-tumor mucosae and cancer lesions. Collectively, these findings suggest that HOTTIP and HOXA13 play important roles in gastric cancer progression and provide a new insight into therapeutic treatment for the disease.
\end{abstract}

\section{Introduction}

Gastric cancer is the second leading cause of cancer-related death worldwide (1). For most patients, gastric cancer is only diagnosed at the advanced stages with poor prognosis $(2,3)$. Gastric carcinogenesis is known as a multistep process involving a series of epigenetic and genetic alterations (4-11). The mechanism of gastric carcinogenesis has not yet been

Correspondence to: Dr Xiangming Che, Department of General Surgery, The First Affiliated Hospital of Xi'an Jiaotong University, 277 West Yanta Road, Xi'an, Shaanxi 710061, P.R. China

E-mail: chexiang@mail.xjtu.edu.cn

Key words: gastric cancer, HOTTIP, HOXA13, lncRNA, oncogene fully elucidated and more studies are needed to search for novel molecules which are involved in the process.

Long non-coding RNAs (lncRNAs) are RNA transcripts which are $>200 \mathrm{bp}$ in length and do not encode for a protein $(12,13)$. Studies suggest that IncRNAs constitute an important component of tumor biology (14-18). Most lncRNAs play a functional role in gene expression by targeting either genomically local or distant genes (19-21). Evidence suggests that IncRNAs play essential roles in tumorigenesis (14,22-24) and cancer progression $(15,25-27)$ by acting as either oncogenes or tumor suppressors.

The regulation of $H O X$ genes by lncRNAs is gaining great interest in developmental biology research. $H O X$ genes are highly conserved at the genomic level. The proteins which $H O X$ genes encode are master regulators of embryonic development and continue to be expressed throughout adulthood in various tissues. HOXA transcript at the distal tip (HOTTIP) is at the $5^{\prime}$ end of the $H O X A$ cluster and upregulates the expression of 5' HOXA genes by binding the adaptor protein WDR5 and targeting the WDR5/MLL complex (28). Evidence suggests that HOTTIP and homeobox protein Hox-A13 (HOXA13) are both upregulated and associated with progression and poor survival of hepatocellular carcinoma (29). Moreover, the expression of HOTTIP and HOXA13 showed a high correlation in hepatocellular carcinoma (29). The role of HOTTIP has also been investigated in pancreatic $(30,31)$ and lung cancer, and tongue squamous cell carcinoma $(32,33)$. For example, HOTTIP promoted disease progression and gemcitabine resistance by regulating HOXA13 in pancreatic cancer (30). In addition, HOTTIP promoted tumor growth and inhibited cell apoptosis in lung cancer (32). In addition, HOTTIP was found to be highly expressed and correlated with the progression of tongue squamous cell carcinoma (33). However, the role of HOTTIP in gastric cancer has never been reported.

In the present study, we investigated the expression of HOTTIP in gastric tissues and the function of HOTTIP in gastric cancer cells, with the aim of elucidating the mechanisms of gastric carcinogenesis and progression.

\section{Materials and methods}

Cell culture. Human immortal gastric epithelial cell line GES-1 and human gastric cancer cell lines SGC7901, MKN28, 
Table I. The sequences of siRNAs used in the present study.

\begin{tabular}{llc}
\hline siRNAs & \multicolumn{1}{c}{ Sense (5'-3') } & Antisense (5'-3') \\
\hline NC & UUCUCCGAACGUGUCACGUTT & ACGUGACACGUUCGGAGAATT \\
siHOTTIP \#1 & GCUUUAGAGCCACAUACUUTT & AAGUAUGUGGCUCUAAAGCTT \\
siHOTTIP \#2 & GAGACAGAGUAGGGUUCUATT & UAGAACCCUACUCUGUCUCTT \\
siHOTTIP \#3 & GGCACUUUAUAUGCUGUAATT & UUACAGCAUAUAAAGUGCCTT \\
siHOXA13 \#1 & GCCACGAAUAAAUUCAUUATT & UAAUGAAUUUAUUCGUGGCTT \\
siHOXA13 \#3 & GCGGACAAGUACAUGGAUATT & UAUCCAUGUACUUGUCCGCTT \\
\hline
\end{tabular}

Table II. qRT-PCR primers used in the present study.

\begin{tabular}{lll}
\hline Genes & \multicolumn{1}{c}{ Forward primer (5'-3') } & \multicolumn{1}{c}{ Reverse primer (5'-3') } \\
\hline GAPDH & GACTCATGACCACAGTCCATGC & AGAGGCAGGGATGATGTTCTG \\
HOTTIP & CCTAAAGCCACGCTTCTTTG & TGCAGGCTGGAGATCCTACT \\
HOXA13 & TGGAACGGCCAAATGTACTG & TGGCGTATTCCCGTTCAAGT \\
HOXA11 & GTACTTACTACGTCTCGGGTCCAG & AGTCTCTGTGCACGAGCTCCT \\
HOXA10 & GGGGACTTCTCTTCCAGTTTC & GGGAGAATTGTGGTGTGCTT \\
HOXA9 & CCACGCTTGACACTCACACT & AGTTGGCTGCTGGGTTATTG
\end{tabular}

MKN45 and MGC803 were obtained from the Cell Resource Center, Shanghai Institute of Biochemistry and Cell Biology at the Chinese Academy of Sciences. Cells were cultured in RPMI-1640 medium supplemented with $10 \%$ fetal bovine serum (FBS) (both from Gibco, Carlsbad, CA, USA) at $37^{\circ} \mathrm{C}$ in a humidified incubator containing $5 \%$ carbon dioxide.

Small interfering RNA (siRNA) transfection. The siRNA oligonucleotides targeting HOTTIP, HOXA13 and the negative control were obtained from GenePharma Co., Ltd. (Shanghai, China). Transfection of the oligonucleotides was conducted with X-tremeGENE siRNA transfection reagent (Roche Molecular Biochemicals, Indianapolis, IN, USA) according to the manufacturer's instructions. The sequences of siRNAs used in the present study are listed in Table I.

RNA extraction and quantitative real-time PCR. Total RNA was extracted from cells or tissues using TRIzol reagent (Invitrogen, Carlsbad, CA, USA) according to the manufacturer's instructions. The cDNA was synthesized using the RevertAid First Strand cDNA Synthesis kit (Thermo Fisher Scientific, Inc., Rockford, IL, USA). Quantitative real-time PCR was performed using a SYBR Premix Ex Taq ${ }^{\mathrm{TM}}$ II (Takara Biotechnology Co., Ltd., Dalian, China) on a Bio-Rad CFX-96 Real-Time PCR system. GAPDH was used as an internal control. The sequences of the primers are listed in Table II. All qRT-PCR reactions were performed in triplicate.

Cell proliferation and colony formation assays. Cell proliferation was measured by the Cell Counting Kit-8 (CCK-8) assay (7Sea Biotech Co., Ltd., Shanghai, China). Cells transfected with siRNA were seeded and cultured into 96-well plates
( $3 \times 10^{3}$ cells/well) in $100 \mu 1$ medium. At different time points indicated in the figures, $10 \mu \mathrm{lCCK}-8$ solution was added into the medium and further incubated with the cells for $3 \mathrm{~h}$. The optical density (OD) was measured using a microplate reader at $450 \mathrm{~nm}$. The CCK-8 assays were performed in triplicate.

For colony formation assay, cells transfected with different siRNAs were seeded into 6-well plates at 300 cells/well. After 14 days of incubation, cells were fixed with methyl alcohol and stained with $0.5 \%$ crystal violet. The number of colonies ( $\geq 50$ cells/colony) was counted. Each experiment was performed in triplicate.

Cell migration and invasion assays. For migration assays, $5 \times 10^{4}$ cells were plated in the top chamber with a non-coated membrane (24-well insert; pore size, $8-\mu \mathrm{m}$; Corning, Corning, NY, USA). For invasion assays, $1.5 \times 10^{5}$ cells were plated in the top chamber with a Matrigel-coated membrane (24-well insert; pore size, $8-\mu \mathrm{m}$; Corning). Medium without serum was used in the top chamber in both assays. Medium with $10 \%$ FBS was added to the lower chamber. After incubation for $24 \mathrm{~h}$ (migration assay) or $48 \mathrm{~h}$ (invasion assay), respectively, the cells that did not migrate or invade through the pores were removed using a cotton swab. Cells on the lower surface of the membrane were fixed with $4 \%$ paraformaldehyde and stained with $0.1 \%$ crystal violet. The number of migrated or invaded cells was counted. Each experiment was performed in triplicate.

Western blot analysis. Cells were lysed with RIPA buffer containing complete protease inhibitor mixture (Roche Molecular Biochemicals). Proteins were separated by dodecyl sulfate-polyacrylamide gel electrophoresis (SDS-PAGE) and 
A

A B

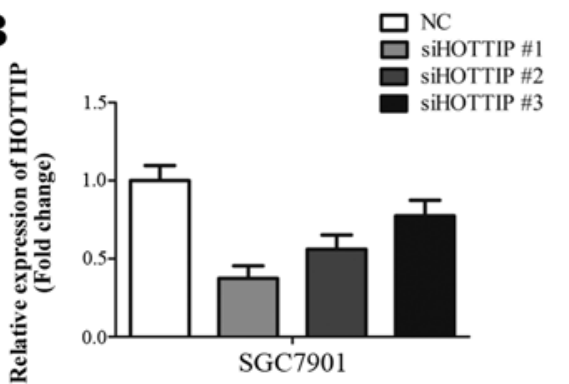

C

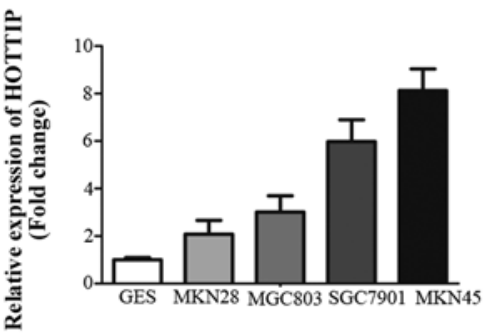

C

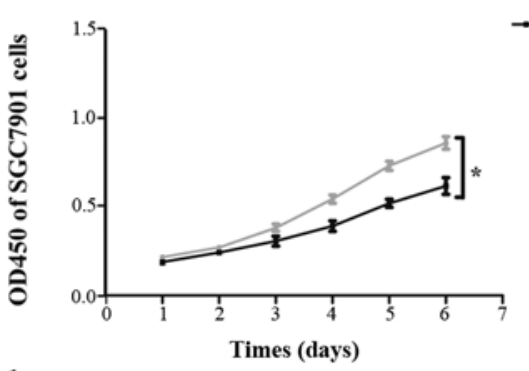

$\rightarrow \mathrm{NC}$

- siHOTTIP \#1

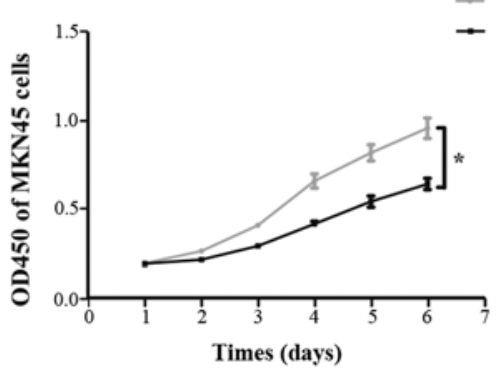

D1

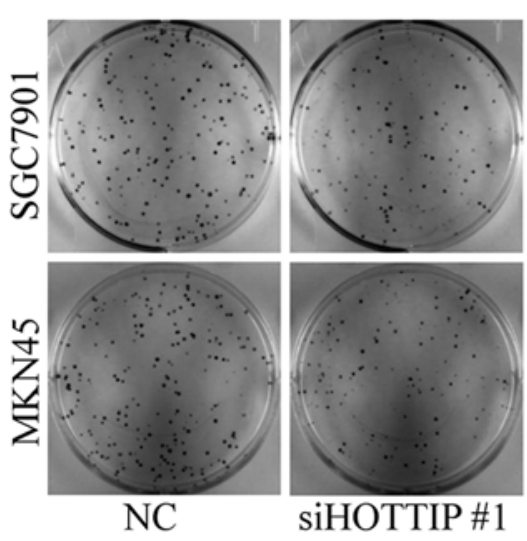

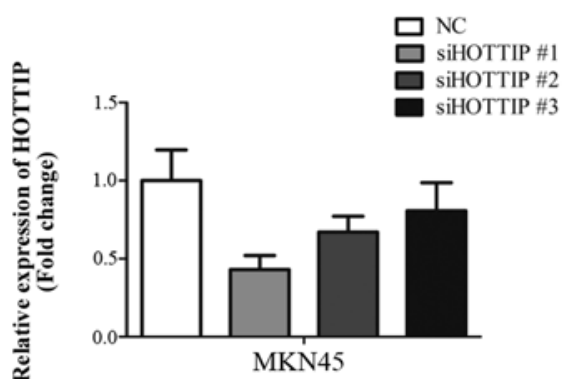

$\rightarrow \mathrm{NC}$

D2
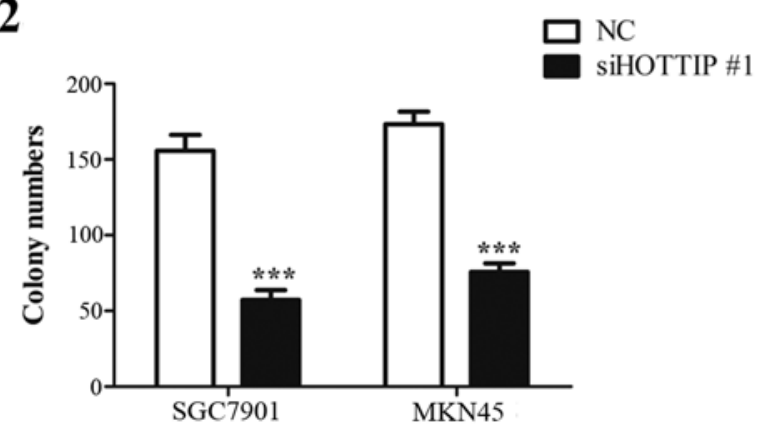

Figure 1. HOTTIP is upregulated in gastric cancer cells and downregulation of HOTTIP inhibits cell growth in SGC7901 and MKN45 cells. (A) Expression of HOTTIP was investigated in the GES-1, MKN28, MGC803, SGC7901 and MKN45 cell lines by qRT-PCR. (B) Efficiency of HOTTIP knockdown was investigated by qRT-PCR $48 \mathrm{~h}$ after siRNA treatment in the SGC7901 and MKN45 cells. (C) HOTTIP knockdown significantly inhibited cell proliferation in the SGC7901 and MKN45 cells. (D1 and D2) The effect of HOTTIP knockdown on cell growth was further investigated by colony formation assay. A representative experiment (D1) and quantitative analysis (D2) are shown. ${ }^{*} \mathrm{P}<0.05 ;{ }^{* * *} \mathrm{P}<0.01 ;{ }^{* * *} \mathrm{P}<0.001$.

transferred to nitrocellulose membranes (Pall Life Sciences, Ann Arbor, MI, USA). The membranes were blocked in 5\% non-fat milk and blotted with antibodies against GAPDH $(1: 2,000)$ and HOXA13 (1:200) (both from Santa Cruz Biotechnology, Inc., Santa Cruz, CA, USA), respectively. The membranes were then incubated with horseradish peroxidase-conjugated secondary antibodies and visualized with an enhanced chemiluminescence reagent.

Tissue samples. A total of 50 paired gastric tissue samples (cancer lesions and adjacent non-tumor mucosae) of gastric cancer patients were obtained from the Department of General Surgery, The First Affiliated Hospital of Xi'an Jiaotong University between June 2013 and February 2014. All patients did not receive chemotherapy or radiotherapy prior to surgery. All samples were collected in the same manner. The samples were immediately frozen in liquid nitrogen and stored at $-80^{\circ} \mathrm{C}$ until they were used. Informed consent was obtained from each patient before the surgery. The present study was approved by the Research Ethics Committee of Xi'an Jiaotong University.
Statistical analysis. Statistical analysis was performed using IBM SPSS Statistics software (IBM Corp., Armonk, NY, USA). Student's t-test for parametric variables was used. Spearman test was used to establish the correlation between HOTTIP and HOXA13. Data are presented as mean \pm SEM unless otherwise indicated. All P-values were determined from two-sided tests, and statistical significance was determined based on a P-value of 0.05 .

\section{Results}

HOTTIP is upregulated in gastric cancer cells and downregulation of HOTTIP inhibits cancer cell growth. To determine the role of HOTTIP in gastric cancer, we first investigated the expression of HOTTIP in the GES-1, MKN28, MGC803, SGC7901 and MKN45 cell lines. In addition, we found that HOTTIP was upregulated in gastric cancer cell lines compared with that noted in the GES-1 cells (Fig. 1A). Then, we investigated the effect of HOTTIP on cell growth by downregulating HOTTIP expression in the SGC7901 and MKN45 

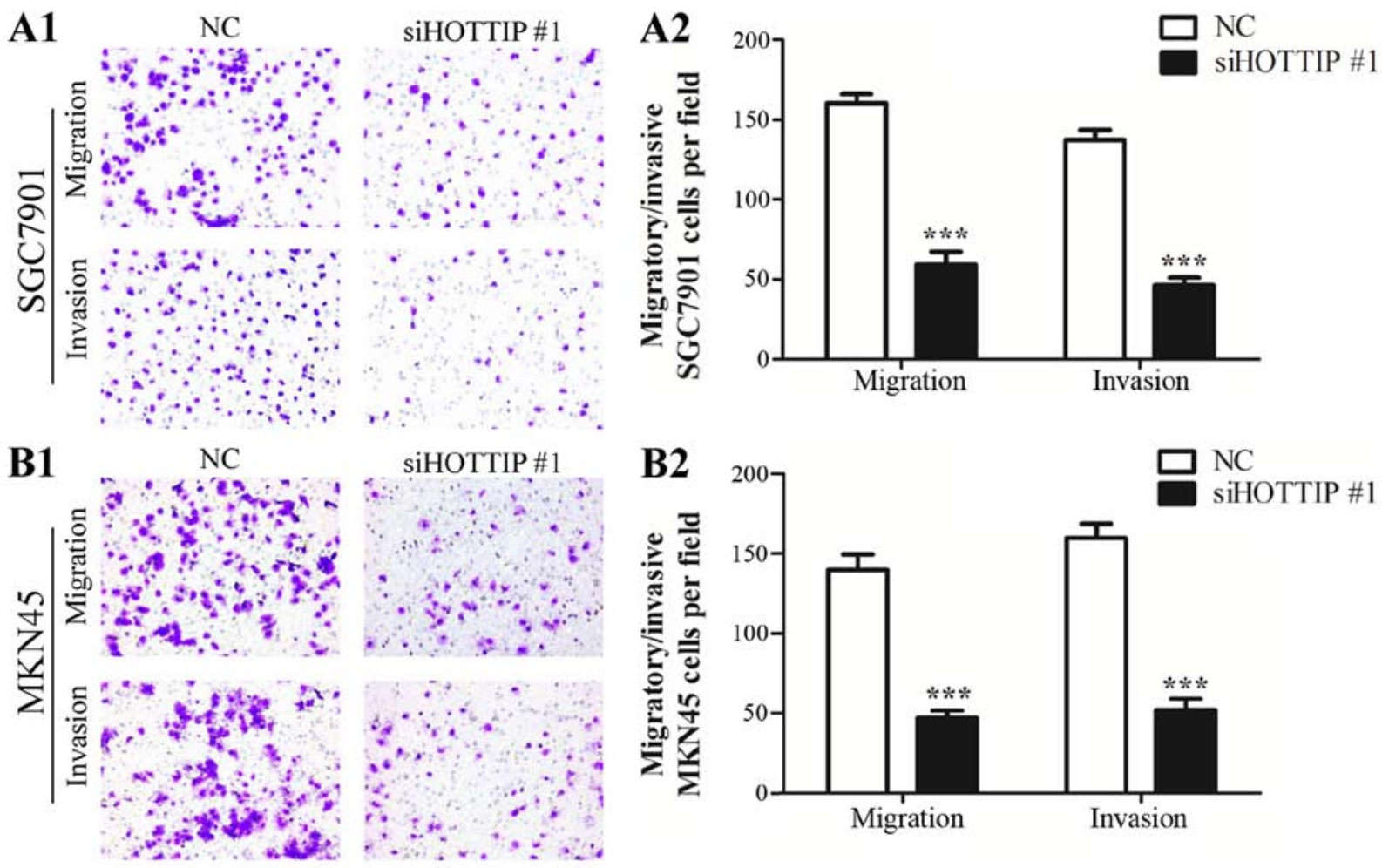

Figure 2. Inhibition of cell migration and invasion by HOTTIP knockdown in gastric cancer cells. (A1 and A2) The effect of HOTTIP knockdown on SGC7901 cells using Transwell migration and invasion assays. (B1 and B2) The effect of HOTTIP knockdown on MKN45 cells using Transwell migration and invasion assays; ${ }^{* * *} \mathrm{P}<0.001$.

cells. Efficiency of HOTTIP knockdown in the SGC7901 and MKN45 cells by three specific siRNAs was confirmed by qRT-PCR and siHOTTIP \#1 was used in the following experiments (Fig. 1B). Knockdown of HOTTIP inhibited cell proliferation in the SGC7901 and MKN45 cells (Fig. 1C). The inhibition of cell growth by HOTTIP knockdown was further confirmed by colony formation assay. Downregulation of HOTTIP decreased colony numbers in the SGC7901 and MKN45 cells (Fig. 1D1 and D2). These results suggest that HOTTIP plays a growth-promoting role in gastric cancer cells.

Downregulation of HOTTIP inhibits cell migration and invasion in gastric cancer. We next investigated the effect of HOTTIP on the migration and invasion of SGC7901 and MKN45 cells. Downregulation of HOTTIP led to a 2- to 3-fold reduction in the migratory and invasive capabilities of the SGC7901 cells (Fig. 2A1 and A2). Similar results were observed in the MKN45 cells with decreased expression of HOTTIP (Fig. 2B1 and B2). These results suggest that HOTTIP promotes both migration and invasion of gastric cancer cells.

Downregulation of HOTTIP leads to decreased HOXA13 expression in gastric cancer cells. HOTTIP knockdown was previously found to lead to a reduction in HOXA gene expression in primary human fibroblasts (28), hepatocellular carcinoma (29) and pancreatic cancer cells $(30,31)$. To ascertain whether HOTTIP exhibits a similar function in gastric cancer cells, we measured the expression of several HOXA genes (HOXA13, HOXA11, HOXA10 and HOXA9) in the SGC7901 cells treated with siHOTTIP \#1. Downregulation of HOTTIP led to different degrees of decrease in the expression levels of these genes, among which HOXA13 expression was decreased the most (Fig. 3A). Downregulation of HOXA13 expression was further confirmed in MKN45 cells by qRT-PCR (Fig. 3A). Knockdown of HOTTIP inhibited the HOXA13 protein level in the SGC7901 and MKN45 cells (Fig. 3B). These results suggest that HOTTIP regulates HOXA13 expression in gastric cancer cells.

HOXA13 is involved in HOTTIP-induced malignant phenotypes of gastric cancer cells. We investigated the expression of HOXA13 in the GES-1 and gastric cancer cell lines. HOXA13 was upregulated in the gastric cancer cell lines compared with GES-1, which was similar to the HOTTIP expression pattern (Fig. 4A). To investigate the role of HOXA13 in gastric cancer, three specific siRNAs against HOXA13 were used to inhibit HOXA13 mRNA expression in the SGC7901 and MKN45 cells. siHOXA13 \#2 showed most significant knockdown efficiency and was used in the following experiments (Fig. 4B). siHOXA13 \#2 led to a clear reduction in the protein level of HOXA13 (Fig. 4C).

Knockdown of HOXA13 also inhibited cell growth (Fig. 5A and B), migration and invasion (Fig. 5C) in the SGC7901 and MKN45 cells, which resembled the inhibitory effects of HOTTIP knockdown. These results indicate that HOXA13 was involved in HOTTIP-induced malignant phenotypes of gastric cancer cells.

HOTTIP and HOXA13 are both upregulated in gastric cancer. To further understand the relationship between HOTTIP and HOXA13 in gastric cancer, we investigated HOTTIP and 
A
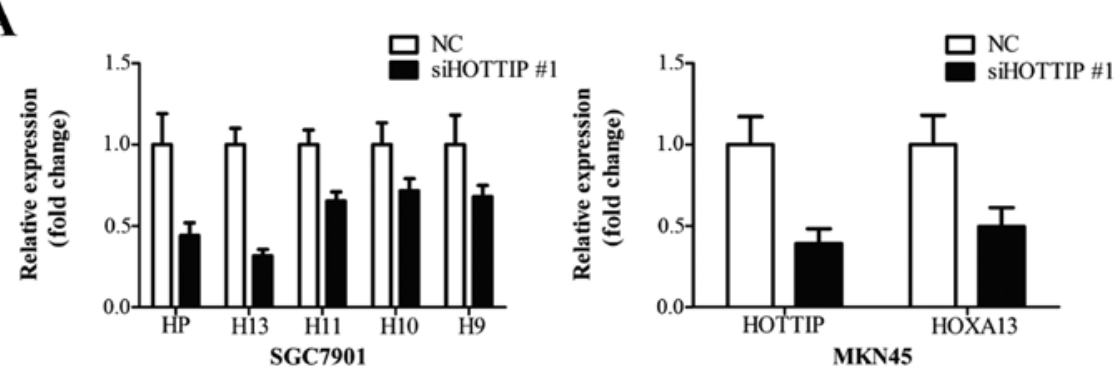

B

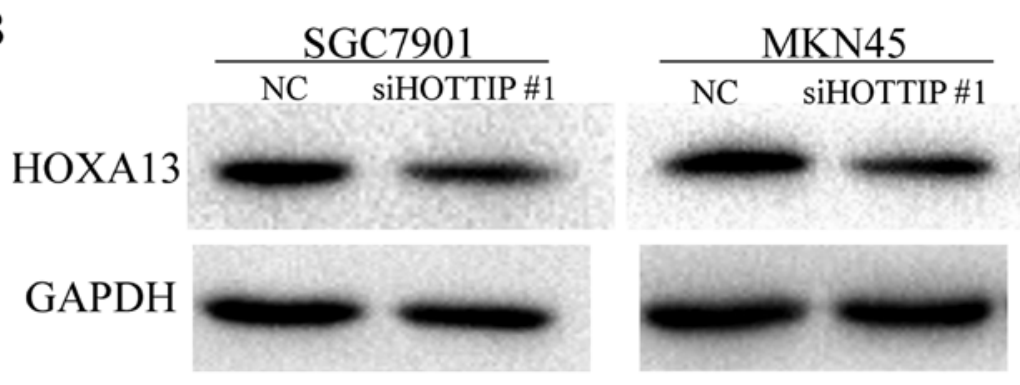

Figure 3. Inhibition of HOXA13 expression by HOTTIP knockdown in gastric cancer cells. (A) Knockdown of HOTTIP inhibited HOXA gene expression in the SGC7901 cells, and inhibition of HOXA13 was further confirmed in the MKN45 cells by qRT-PCR. HP, HOTTIP; H13, HOXA13; H11, HOXA11; H10, HOXA10; and H9, HOXA9. (B) Knockdown of HOTTIP inhibited HOXA13 protein levels in the SGC7901 and MKN45 cells.

A

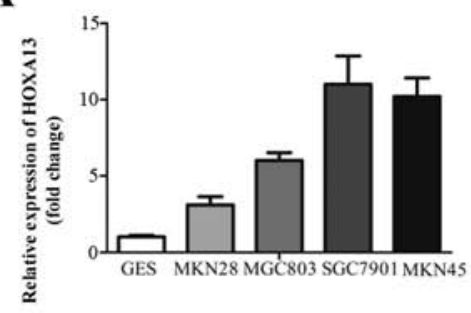

B

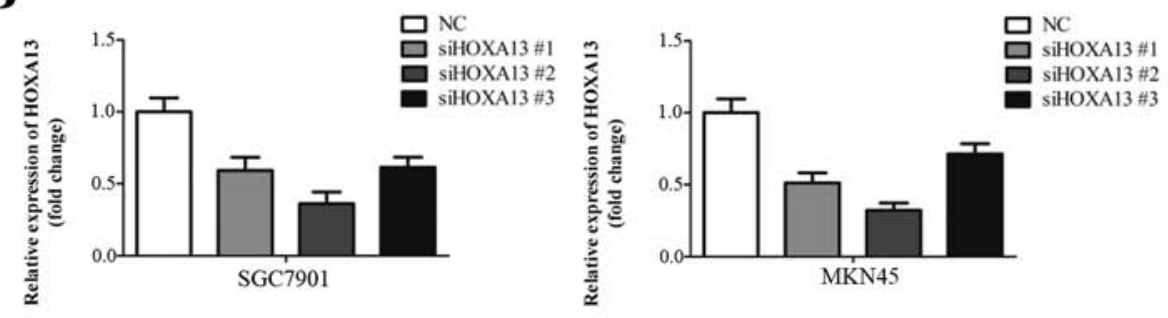

C
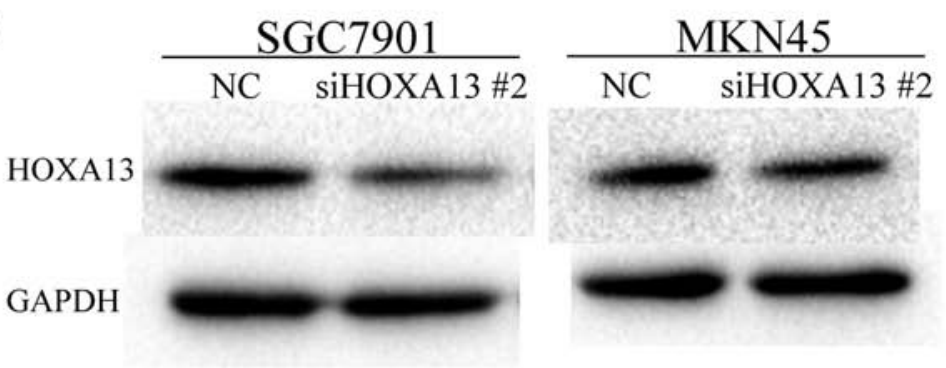

Figure 4. Overexpression of HOXA13 in gastric cancer cell lines and efficiency of HOXA13 knockdown in the SGC7901 and MKN45 cells. (A) Expression of HOXA13 mRNA in the GES and gastric cancer cell lines was investigated. (B) Efficiency of HOXA13 knockdown was investigated by qRT-PCR 48 h after siRNA treatment in the SGC7901 and MKN45 cells. (C) HOXA13 protein expression was inhibited by siHOXA13 \#2 in the SGC7901 and MKN45 cells.

HOXA13 expression levels in 50 pairs of primary gastric cancer tissues and their counterpart non-tumorous tissues by qRT-PCR. The results showed that HOTTIP and HOXA13 were both markedly upregulated in the gastric cancer tissues when compared with these levels in the non-tumorous tissues (Fig. 6A and B), which were consistent with the expression patterns of HOTTIP and HOXA13 in the gastric cancer cells. Correlations between the HOTTIP or HOXA13 expression levels and clinicopathologic characteristics of gastric cancer are summarized in Tables III or IV, respectively. The data revealed that expression levels of HOTTIP and HOXA13 were both higher in gastric cancer which was poorly differen- tiated $(\mathrm{P}<0.05)$, at advanced TNM stages $(\mathrm{P}<0.05)$ and showed lymph node metastasis $(\mathrm{P}<0.01)$. Spearman analyses indicated that HOTTIP and HOXA13 had a positive correlation both in non-tumor mucosae (Fig. 6C) and cancer lesions (Fig. 6D). These results suggest that HOTTIP and HOXA13 are highly correlated and associated with gastric cancer progression.

\section{Discussion}

In the present study, we found that both HOTTIP and HOXA13 were upregulated in gastric cancer tissues compared with levels in their counterpart non-tumorous tissues. In 
A

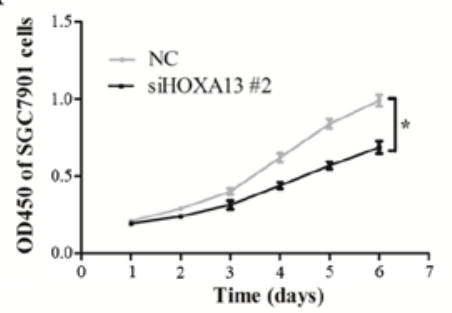

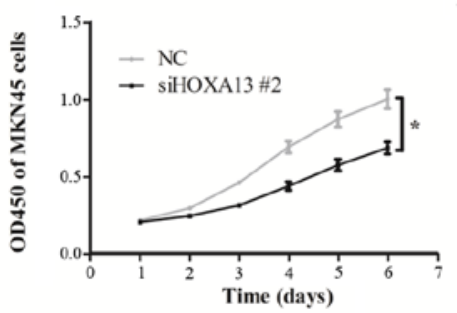

B

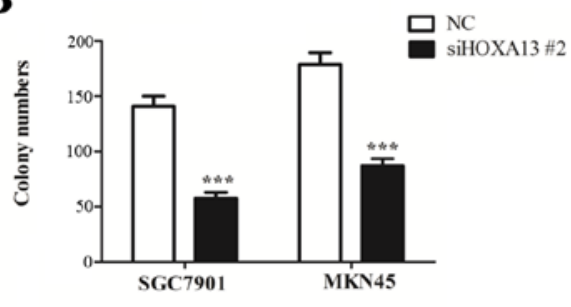

C
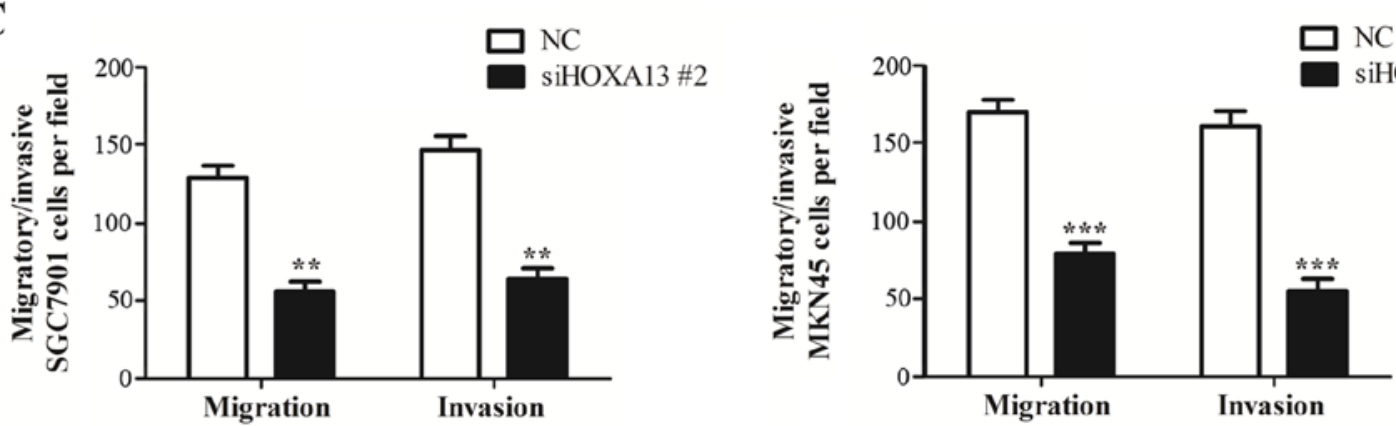

Figure 5. Inhibition of cell growth, migration and invasion by HOXA13 knockdown in gastric cancer cells. (A) HOXA13 knockdown significantly inhibited cell proliferation in the SGC7901 and MKN45 cells. (B) The effect of HOXA13 knockdown on cell growth was further investigated by colony formation assay. (C) The effect of HOXA13 knockdown on SGC7901 and MKN45 cells as assessed by Transwell migration and invasion assays. ${ }^{*} \mathrm{P}<0.05 ;{ }^{* *} \mathrm{P}<0.01 ;{ }^{* * * *} \mathrm{P}<0.001$.
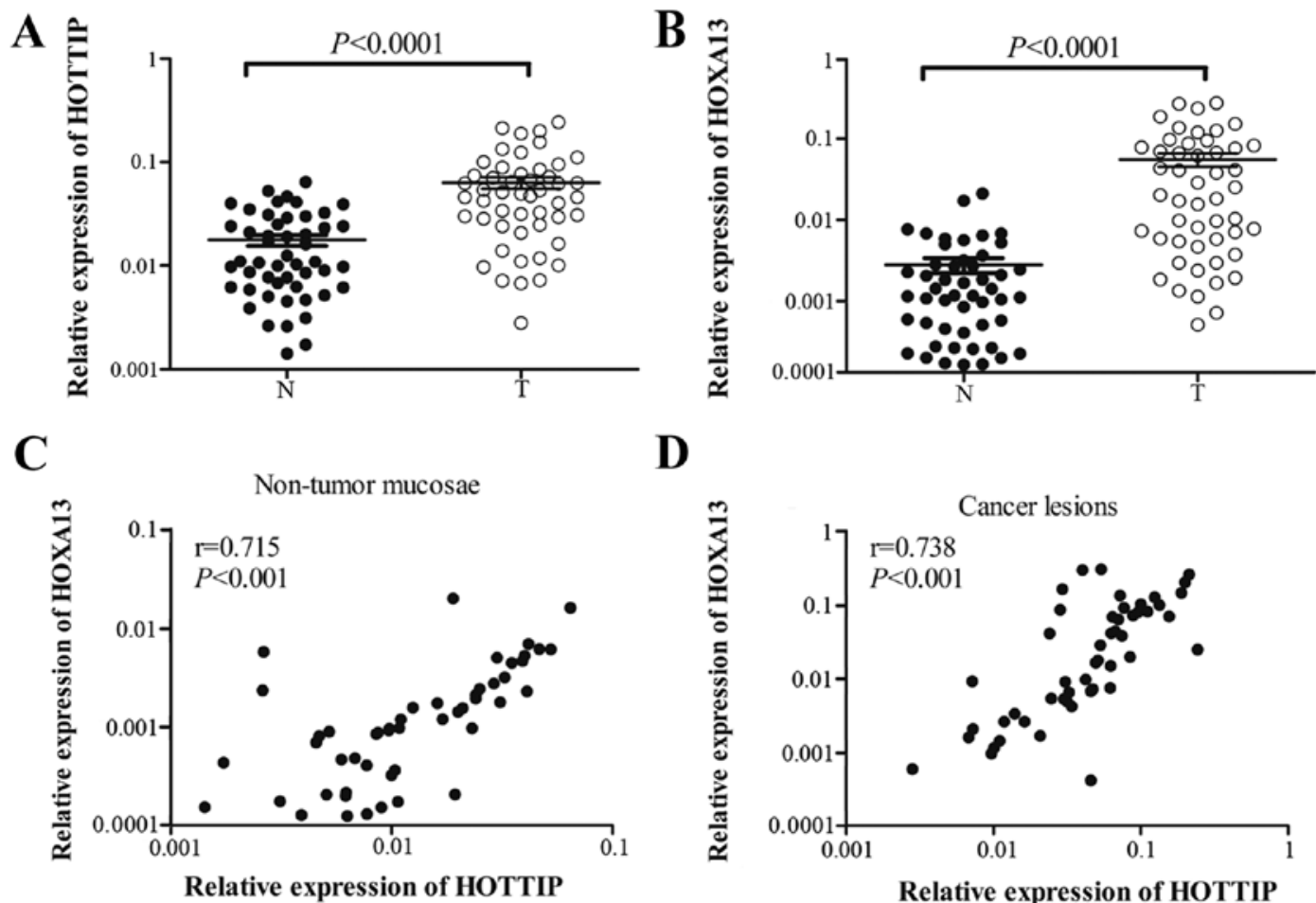

D

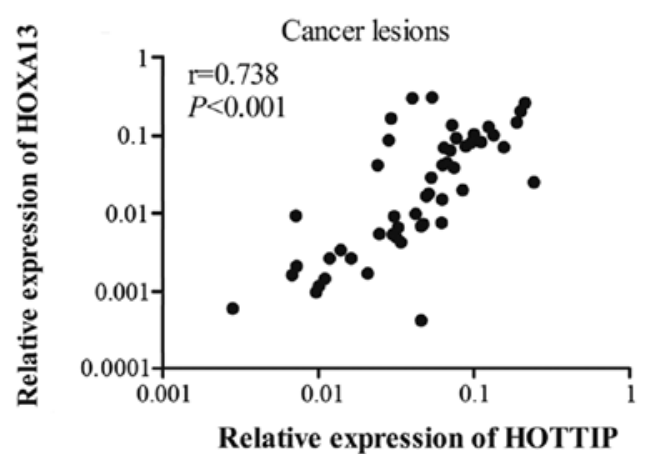

Figure 6. Comparison of HOTTIP and HOXA13 expression in tissue samples. (A and B) Expression levels of HOTTIP (A) and HOXA13 (B) were investigated by qRT-PCR in 50 paired human gastric cancer samples $(\mathrm{T})$ and their counterpart non-tumorous samples $(\mathrm{N})$. The expression levels of HOTTIP and HOXA13 were normalized to GAPDH using the $2^{-\Delta \mathrm{Ct}}\left(-\Delta \mathrm{Ct}=\mathrm{Ct}_{\mathrm{GAPDH}}-\mathrm{Ct}_{\mathrm{Gene}}\right)$ method. The y-axis $\left(\log _{10}\right.$ scale) was used to describe the relative levels of HOTTIP and HOXA13. (C and D) Correlation scatterplot of HOTTIP and HOXA13 expression in non-tumor mucosae (C) and cancer lesions (D).

addition, the expression levels of HOTTIP and HOXA13 were associated with poor differentiation, advanced TNM stages and lymph node metastasis. Moreover, HOTTIP and HOXA13 were highly correlated both in non-tumor mucosae and cancer lesions. Downregulation of HOTTIP inhibited cell growth and invasion. In addition, HOXA13 was involved in HOTTIP-induced malignant phenotypes of gastric cancer cells.

IncRNAs associated with human $H O X$ gene loci have been widely studied in recent years $(21,28,34-36)$. By character- 
Table III. Relationship between HOTTIP expression and clinicopathological parameters in the primary gastric cancer cases.

\begin{tabular}{|c|c|c|c|c|}
\hline Variable & $\begin{array}{l}\text { No. of } \\
\text { cases }\end{array}$ & $\%$ & $\begin{array}{c}\text { Relative } \\
\text { expression } \\
\text { of HOTTIP }\end{array}$ & P-value \\
\hline Age (years) & & & & 0.226 \\
\hline$\geq 60$ & 29 & 58 & $0.0716 \pm 0.0116$ & \\
\hline$<60$ & 21 & 42 & $0.0518 \pm 0.00995$ & \\
\hline Gender & & & & 0.384 \\
\hline Male & 38 & 76 & $0.0672 \pm 0.0103$ & \\
\hline Female & 12 & 24 & $0.0508 \pm 0.00652$ & \\
\hline Tumor size $(\mathrm{cm})$ & & & & 0.362 \\
\hline$\geq 5$ & 28 & 56 & $0.0698 \pm 0.0111$ & \\
\hline$<5$ & 22 & 44 & $0.0550 \pm 0.0115$ & \\
\hline $\begin{array}{l}\text { Degree of } \\
\text { differentiation }\end{array}$ & & & & 0.0250 \\
\hline Well/moderate & 27 & 54 & $0.0469 \pm 0.00888$ & \\
\hline Poor & 23 & 46 & $0.0825 \pm 0.0130$ & \\
\hline TNM stage & & & & 0.00240 \\
\hline $\mathrm{I} / \mathrm{II}$ & 15 & 30 & $0.0274 \pm 0.00230$ & \\
\hline III/IV & 35 & 70 & $0.0787 \pm 0.0104$ & \\
\hline Lymph node status & & & & 0.00950 \\
\hline Metastasis & 38 & 76 & $0.0747 \pm 0.00971$ & \\
\hline No metastasis & 12 & 24 & $0.0272 \pm 0.00473$ & \\
\hline
\end{tabular}

izing the transcriptional landscape of the four human $H O X$ loci, researchers have identified 231 HOX lncRNAs (21). HOTAIR, which was first described in fibroblasts, was found to be located in the HOXC cluster but regulated $H O X D$ cluster genes (21). HOTAIR was also found to serve as a scaffold protein by binding polycomb repressive complex 2 (PRC) with its 5' domain and the LSD1/CoREST/REST complex with the 3 ' domain (37). Unlike HOTAIR, HOTTIP enhanced expression of neighboring HOXA genes particularly HOXA13 (28). Considering the vital role of $H O X$ genes in development and differentiation and their dysregulation-caused tumorigenesis and tumor progression (38-42), it is important to understand the mechanism of HOTTIP in the regulation of HOX gene expression.

Upregulation of HOTTIP and HOXA13 has been reported in various studies. HOTTIP and HOXA13 were both upregulated and highly correlated in hepatocellular carcinoma (29) and pancreatic cancer $(31,32)$. A previous study demonstrated that HOTTIP was upregulated not only in hepatocellular carcinoma tissues, but also in preneoplastic diseases. However, the HOXA13 expression level was specifically increased in hepatocellular carcinoma, indicating that upregulation of HOTTIP preceded that of HOXA13 in hepatocellular carcinogenesis during disease onset (29). HOTTIP was also found to be upregulated in lung cancer (32) and tongue squamous cell carcinoma (33), and involved in the tumor progression in pancreatic cancer (30). The expression level of HOXA13 was also increased and associated with tumor progression
Table IV. Relationship between HOXA13 expression and clinicopathological parameters in the primary gastric cancer cases.

\begin{tabular}{|c|c|c|c|c|}
\hline Variable & $\begin{array}{l}\text { No. of } \\
\text { cases }\end{array}$ & $\%$ & $\begin{array}{c}\text { Relative } \\
\text { expression } \\
\text { of HOXA13 }\end{array}$ & P-value \\
\hline Age (years) & & & & 0.520 \\
\hline$\geq 60$ & 29 & 58 & $0.0618 \pm 0.0152$ & \\
\hline$<60$ & 21 & 42 & $0.0476 \pm 0.0149$ & \\
\hline Gender & & & & 0.615 \\
\hline Male & 38 & 76 & $0.0589 \pm 0.0131$ & \\
\hline Female & 12 & 24 & $0.0461 \pm 0.0175$ & \\
\hline Tumor size (cm) & & & & 0.368 \\
\hline$\geq 5$ & 28 & 56 & $0.0645 \pm 0.0169$ & \\
\hline$<5$ & 22 & 44 & $0.0448 \pm 0.0116$ & \\
\hline $\begin{array}{l}\text { Degree of } \\
\text { differentiation }\end{array}$ & & & & 0.0178 \\
\hline Well/moderate & 27 & 54 & $0.0327 \pm 0.00832$ & \\
\hline Poor & 23 & 46 & $0.0831 \pm 0.0199$ & \\
\hline TNM stage & & & & 0.0192 \\
\hline $\mathrm{I} / \mathrm{II}$ & 15 & 30 & $0.0179 \pm 0.00674$ & \\
\hline III/IV & 35 & 70 & $0.0721 \pm 0.0143$ & \\
\hline Lymph node status & & & & 0.00550 \\
\hline Metastasis & 38 & 76 & $0.0722 \pm 0.0131$ & \\
\hline No metastasis & 12 & 24 & $0.00409 \pm 0.000987$ & \\
\hline
\end{tabular}

in hepatocellular carcinoma (29), pancreatic cancer (30), esophageal squamous cell carcinoma (43) and glioblastoma multiforme (44). A recent study found that HOXA13 expression was higher in cancerous tissues compared with that in their neighboring non-cancerous tissues. Moreover, a higher expression level of HOXA13 was significantly correlated with $\mathrm{T}$ and $\mathrm{M}$ stages, advanced UICC stage and histological differentiation in gastric cancer based on immunohistochemistry findings (45). In the present study, we also found that HOTTIP and HOXA13 were upregulated in gastric cancer tissues compared with level in their non-tumorous tissues. In addition, the increase in the expression level of these two genes was correlated with cancer tissue poor differentiation, advanced TNM stages and lymph node metastasis. HOTTIP and HOXA13 were positively associated in both non-tumor mucosae and cancer lesions. Our findings suggest that HOTTIP and HOXA13 are likely involved in the tumorigenesis and progression of gastric cancer.

Although we identified upregulation of HOTTIP and HOXA13 in gastric cancer, the roles of HOTTIP and HOXA13 in gastric cancer have never been fully understood. Downregulation of HOTTIP and HOXA13 has been reported to inhibit cell proliferation in liver cancer-derived cells (29). HOTTIP and HOXA13 promoted cell proliferation, migration and invasion in pancreatic cancer $(30,31)$. Moreover, HOTTIP regulated the expression of HOXA13 in hepatocellular carcinoma (29) and pancreatic cancer (30). However, Cheng et al showed that HOTTIP regulated HOX genes 
including HOXA10, HOXA11, HOXA9 and HOXA1, but not HOXA13 (31). HOXA13 was found to promote cell growth of esophageal squamous cancer cells in vitro and in vivo (43). HOXA13 also promoted cell invasion in vitro and tumor growth in vivo in glioblastoma multiforme (44). In the present study, we firstly identified that HOTTIP and HOXA13 both promoted cell growth and invasiveness in gastric cancer cells. In addition, downregulation of HOTTIP led to decreased HOXA13 expression in gastric cancer cells. The roles of HOTTIP and HOXA13 in gastric cancer cells in vivo warrant further investigation. Taken together, these data indicate that HOTTIP functions as an oncogene by regulating HOXA13 expression in gastric cancer.

In conclusion, our results showed that HOTTIP and HOXA13 were upregulated and associated with poor differentiation, advanced TNM stages and lymph node metastasis in gastric cancer. HOTTIP and HOXA13 were highly correlated in both non-tumor mucosae and cancer lesions. Downregulation of HOTTIP inhibited gastric cancer cell growth and invasiveness through the regulation of HOXA13. These results suggest that the molecular axis of HOTTIP and HOXA13 contributes to gastric cancer progression. Our finding provides a potential novel therapeutic target for gastric cancer treatment.

\section{Acknowledgements}

The present study was supported in part by the National Natural Science Foundation of China (no. 81472245).

\section{References}

1. Jemal A, Bray F, Center MM, Ferlay J, Ward E and Forman D: Global cancer statistics. CA Cancer J Clin 61: 69-90, 2011.

2. Takahashi T, Saikawa Y and Kitagawa Y: Gastric cancer: Current status of diagnosis and treatment. Cancers 5: 48-63, 2013.

3. Ajani JA, Bentrem DJ, Besh S, D'Amico TA, Das P, Denlinger C, Fakih MG, Fuchs CS, Gerdes H, Glasgow RE, et al; National Comprehensive Cancer Network: Gastric cancer, version 2.2013 Featured updates to the NCCN Guidelines. J Natl Compr Canc Netw 11: 531-546, 2013.

4. Zheng L, Wang L, Ajani J and Xie K: Molecular basis of gastric cancer development and progression. Gastric Cancer 7: 61-77, 2004.

5. Tamura G, Yin J, Wang S, Fleisher AS, Zou T, Abraham JM, Kong D, Smolinski KN, Wilson KT, James SP, et al: E-Cadherin gene promoter hypermethylation in primary human gastric carcinomas. J Natl Cancer Inst 92: 569-573, 2000.

6. Maekita T, Nakazawa K, Mihara M, Nakajima T, Yanaoka K, Iguchi M, Arii K, Kaneda A, Tsukamoto T, Tatematsu M, et al High levels of aberrant DNA methylation in Helicobacter pyloriinfected gastric mucosae and its possible association with gastric cancer risk. Clin Cancer Res 12: 989-995, 2006.

7. Niwa T, Tsukamoto T, Toyoda T, Mori A, Tanaka H, Maekita T, Ichinose $M$, Tatematsu $M$ and Ushijima T: Inflammatory processes triggered by Helicobacter pylori infection cause aberrant DNA methylation in gastric epithelial cells. Cancer Res 70: 1430-1440, 2010

8. El-Omar EM, Carrington M, Chow WH, McColl KE, Bream JH, Young HA, Herrera J, Lissowska J, Yuan CC, Rothman N, et al: Interleukin-1 polymorphisms associated with increased risk of gastric cancer. Nature 404: 398-402, 2000.

9. He C, Tu H, Sun L, Xu Q, Gong Y, Jing J, Dong N and Yuan Y: SNP interactions of Helicobacter pylori-related host genes $P G C$ $P T P N 11, I L 1 B$, and TLR4 in susceptibility to gastric carcinogenesis. Oncotarget 6: 19017-19026, 2015.

10. Huang TT, Ping YH, Wang AM, Ke CC, Fang WL, Huang KH, Lee HC, Chi CW and Yeh TS: The reciprocal regulation loop of Notch2 pathway and miR-23b in controlling gastric carcinogenesis. Oncotarget 6: 18012-18026, 2015.
11. Shen J, Xiao Z, Wu WK, Wang MH, To KF, Chen Y, Yang W, Li MS, Shin VY, Tong JH, et al: Epigenetic silencing of miR-490-3p reactivates the chromatin remodeler SMARCD1 to promote Helicobacter pylori-induced gastric carcinogenesis. Cancer Res 75: 754-765, 2015.

12. Gibb EA, Brown CJ and Lam WL: The functional role of long non-coding RNA in human carcinomas. Mol Cancer 10: 38 , 2011.

13. Flynn RA and Chang HY: Long noncoding RNAs in cell-fate programming and reprogramming. Cell Stem Cell 14: 752-761, 2014.

14. Huarte M and Rinn JL: Large non-coding RNAs: Missing links in cancer? Hum Mol Genet 19: R152-R161, 2010.

15. Prensner JR, Iyer MK, Balbin OA, Dhanasekaran SM, Cao Q, Brenner JC, Laxman B, Asangani IA, Grasso CS, Kominsky HD, et al: Transcriptome sequencing across a prostate cancer cohort identifies $P C A T-1$, an unannotated lincRNA implicated in disease progression. Nat Biotechnol 29: 742-749, 2011.

16. Braconi C, Valeri N, Kogure T, Gasparini P, Huang N, Nuovo GJ, Terracciano L, Croce CM and Patel T: Expression and functional role of a transcribed noncoding RNA with an ultraconserved element in hepatocellular carcinoma. Proc Natl Acad Sci USA 108: 786-791, 2011.

17. Pantoja C, de Los Ríos L, Matheu A, Antequera F and Serrano M: Inactivation of imprinted genes induced by cellular stress and tumorigenesis. Cancer Res 65: 26-33, 2005.

18. Yap KL, Li S, Muñoz-Cabello AM, Raguz S, Zeng L, Mujtaba S, Gil J, Walsh MJ and Zhou MM: Molecular interplay of the noncoding RNA ANRIL and methylated histone H3 lysine 27 by polycomb CBX7 in transcriptional silencing of INK4a. Mol Cell 38: 662-674, 2010.

19. Brown CJ, Ballabio A, Rupert JL, Lafreniere RG, Grompe M, Tonlorenzi R and Willard HF: A gene from the region of the human $\mathrm{X}$ inactivation centre is expressed exclusively from the inactive X chromosome. Nature 349: 38-44, 1991.

20. Bartolomei MS, Zemel S and Tilghman SM: Parental imprinting of the mouse H19 gene. Nature 351: 153-155, 1991.

21. Rinn JL, Kertesz M, Wang JK, Squazzo SL, Xu X, Brugmann SA, Goodnough LH, Helms JA, Farnham PJ, Segal E, et al: Functional demarcation of active and silent chromatin domains in human HOX loci by noncoding RNAs. Cell 129: 1311-1323, 2007.

22. Hou P, Zhao Y, Li Z, Yao R, Ma M, Gao Y, Zhao L, Zhang Y, Huang B and Lu J: LincRNA-ROR induces epithelial-to-mesenchymal transition and contributes to breast cancer tumorigenesis and metastasis. Cell Death Dis 5: e1287, 2014.

23. Zhang H, Diab A, Fan H, Mani SK, Hullinger R, Merle P and Andrisani O: PLK1 and HOTAIR accelerate proteasomal degradation of SUZ12 and ZNF198 during hepatitis B virus-induced liver carcinogenesis. Cancer Res 75: 2363-2374, 2015.

24. Fan J, Xing Y, Wen X, Jia R, Ni H, He J, Ding X, Pan H, Qian G, $\mathrm{Ge} \mathrm{S}$, et al: Long non-coding RNA ROR decoys gene-specific histone methylation to promote tumorigenesis. Genome Biol 16: 139, 2015.

25. Barnhill LM, Williams RT, Cohen O, Kim Y, Batova A, Mielke JA, Messer K, Pu M, Bao L, Yu AL, et al: High expression of $C A I 2$, a 9p21-embedded long noncoding RNA, contributes to advanced-stage neuroblastoma. Cancer Res 74: 3753-3763, 2014.

26. Hu Y, Wang J, Qian J, Kong X, Tang J, Wang Y, Chen H, Hong J, Zou W, Chen Y, et al: Long noncoding RNA GAPLINC regulates CD44-dependent cell invasiveness and associates with poor prognosis of gastric cancer. Cancer Res 74: 6890-6902, 2014.

27. Zhang X, Gejman R, Mahta A, Zhong Y, Rice KA, Zhou Y, Cheunsuchon P, Louis DN and Klibanski A: Maternally expressed gene 3, an imprinted noncoding RNA gene, is associated with meningioma pathogenesis and progression. Cancer Res 70: 2350-2358, 2010.

28. Wang KC, Yang YW, Liu B, Sanyal A, Corces-Zimmerman R, Chen Y, Lajoie BR, Protacio A, Flynn RA, Gupta RA, et al: A long noncoding RNA maintains active chromatin to coordinate homeotic gene expression. Nature 472: 120-124, 2011.

29. Quagliata L, Matter MS, Piscuoglio S, Arabi L, Ruiz C, Procino A, Kovac M, Moretti F, Makowska Z, Boldanova T, et al: Long noncoding RNA HOTTIP/HOXA13 expression is associated with disease progression and predicts outcome in hepatocellular carcinoma patients. Hepatology 59: 911-923, 2014.

30. Li Z, Zhao X, Zhou Y, Liu Y, Zhou Q, Ye H, Wang Y, Zeng J, Song Y, Gao W, et al: The long non-coding RNA HOTTIP promotes progression and gemcitabine resistance by regulating HOXA13 in pancreatic cancer. J Transl Med 13: 84, 2015. 
31. Cheng Y, Jutooru I, Chadalapaka G, Corton JC and Safe S: The long non-coding RNA HOTTIP enhances pancreatic cancer cell proliferation, survival and migration. Oncotarget 6: 10840-10852, 2015.

32. Deng HP, Chen L, Fan T, Zhang B, Xu Y and Geng Q: Long non-coding RNA HOTTIP promotes tumor growth and inhibits cell apoptosis in lung cancer. Cell Mol Biol 61: 34-40, 2015.

33. Zhang H, Zhao L, Wang YX, Xi M, Liu SL and Luo LL: Long non-coding RNA HOTTIP is correlated with progression and prognosis in tongue squamous cell carcinoma. Tumour Biol 36 8805-8809, 2015.

34. Maamar H, Cabili MN, Rinn J and Raj A: linc-HOXAl is a noncoding RNA that represses Hoxal transcription in cis. Genes Dev 27: 1260-1271, 2013

35. Zhang EB, Yin DD, Sun M, Kong R, Liu XH, You LH, Han L, Xia R, Wang KM, Yang JS, et al: P53-regulated long non-coding RNA TUG1 affects cell proliferation in human non-small cell lung cancer, partly through epigenetically regulating HOXB7 expression. Cell Death Dis 5: e1243, 2014.

36. Zhang X, Lian Z, Padden C, Gerstein MB, Rozowsky J, Snyder M, Gingeras TR, Kapranov P, Weissman SM and Newburger PE: A myelopoiesis-associated regulatory intergenic noncoding RNA transcript within the human HOXA cluster. Blood 113: 2526-2534, 2009.

37. Tsai MC, Manor O, Wan Y, Mosammaparast N, Wang JK, Lan F, Shi Y, Segal E and Chang HY: Long noncoding RNA as modular scaffold of histone modification complexes. Science 329: 689-693, 2010.

38. Liao WT, Jiang D, Yuan J, Cui YM, Shi XW, Chen CM, Bian XW Deng YJ and Ding YQ: HOXB7 as a prognostic factor and mediator of colorectal cancer progression. Clin Cancer Res 17: 3569-3578, 2011.
39. Cantile M, Pettinato G, Procino A, Feliciello I, Cindolo L and Cillo C: In vivo expression of the whole HOX gene network in human breast cancer.Eur J Cancer 39: 257-264, 2003.

40. Waltregny D, Alami Y, Clausse N, de Leval J and Castronovo V: Overexpression of the homeobox gene HOXC8 in human prostate cancer correlates with loss of tumor differentiation. Prostate 50: 162-169, 2002.

41. Costa BM, Smith JS, Chen Y, Chen J, Phillips HS, Aldape KD, Zardo G, Nigro J, James CD, Fridlyand J, et al: Reversing HOXA9 oncogene activation by PI3K inhibition: Epigenetic mechanism and prognostic significance in human glioblastoma. Cancer Res 70: 453-462, 2010.

42. Buske C, Feuring-Buske M, Abramovich C, Spiekermann K, Eaves CJ, Coulombel L, Sauvageau G, Hogge DE and Humphries RK: Deregulated expression of HOXB4 enhances the primitive growth activity of human hematopoietic cells. Blood 100: 862-868, 2002.

43. Gu ZD, Shen LY, Wang H, Chen XM, Li Y, Ning T and Chen KN: HOXA13 promotes cancer cell growth and predicts poor survival of patients with esophageal squamous cell carcinoma. Cancer Res 69: 4969-4973, 2009.

44. Duan R, Han L, Wang Q, Wei J, Chen L, Zhang J, Kang C and Wang L: HOXA13 is a potential GBM diagnostic marker and promotes glioma invasion by activating the Wnt and TGF- $\beta$ pathways. Oncotarget 6: 27778-27793, 2015.

45. Han Y, Tu WW, Wen YG, Li DP, Qiu GQ, Tang HM, Peng ZH and Zhou CZ: Identification and validation that up-expression of HOXA13 is a novel independent prognostic marker of a worse outcome in gastric cancer based on immunohistochemistry. Med Oncol 30: 564, 2013 